\title{
Talking about Public Service Processes
}

\author{
Bruna Diirr ${ }^{1,2}$, Renata Araujo ${ }^{1,2}$, and Claudia Cappelli ${ }^{1,2}$ \\ ${ }^{1}$ Graduate Program in Information Systems (PPGI), UNIRIO, Av. Pasteur, \\ 458 - Urca - Rio de Janeiro - Cep: 22290-240 - Brazil \\ ${ }^{2}$ NP2Tec - Research and Practice Group in Information Technology, UNIRIO, Av. Pasteur, \\ 458 - Urca - Rio de Janeiro - Cep: 22290-240 - Brazil \\ \{bruna.diirr, renata.araujo, claudia.cappelli\}@uniriotec.br
}

\begin{abstract}
Many discussions enforce the need to encourage Society's involvement and participation in public issues. This paper moves towards the idea that the use of conversations about public services encourages closer ties between Society and Government. It presents a tool to support discussion and share of information about public service processes. The tool also enables the use of information obtained from conversations to identify service improvements.
\end{abstract}

Keywords: Public Process, Collaboration, Transparency, Memory.

\section{Introduction}

A great number of discussions enforce the need to encourage Society's involvement and participation in public issues. In Brazil, a number of Government initiatives attempt to provide information about public services in order to stimulate Society's greater involvement in these issues [1][2][3]. One initiative is the "Charter of services" [4], a document which must be prepared by any public institution to inform citizens about the kind of services are offered, how to access them and how this public organization is committed to providing them. Another initiative comprises public consultations, in order to collect contributions from Society about actions to be performed in different public issues [5][6][7].

Research in e-Democracy and e-Gov enforce ICTs' potential to improve information access. ICTs can be enablers to allow Government to be open to citizens, offer new channels for disseminating information, increase awareness and participation, and improve operations and integration within and between governments [8][9][10][11][12][13].

E-Democracy and e-Gov discussions argue that Society's involvement follows an increasing scale of participation 14. It is argued that closer ties between Government and Society must start from the most basic levels of participation, especially by providing information about public services. However, difficulties are still found in finding effective solutions to provide information and opportunities for participation concerning public services [3][15].

The aim of this paper is to suggest a form of public participation based on conversations about public services. A tool was designed to facilitate the conversations about public services among citizens, between citizens and Government and to allow for 
their analysis. It is proposed that services be presented in process model form, allowing for better understanding of their performance. The tool enables participants (Society and Government) to talk about services, while this data can be organized and used as the basis for service improvement identification.

The paper is structured as follows: Section 2 describes proposals for Society and Government interaction through ICT use; Section 3 presents the proposed approach for talking about public services; Section 4 presents the environment supporting the conversations about public services; finally, section 5 concludes the paper and suggests future work.

\section{Interaction between Society and Government in Public Affairs}

There are several classifications for different participation levels in democratic contexts through ICTs use [14][16][17][18][19]. These classifications show the degree of democratic participation in a scale, from government information provision to public deliberation. At each level, participation, discussion and decision-making power is increased.

The barriers to provide access to citizen participation at each of these levels involve technological, social, cultural and economic aspects [15][20]. Moreover, research on e-Democracy indicates that it is still difficult to find effective solutions encouraging civil society participation in public affairs. The World Economic Forum report on the use of ICTs by governments points to Brazil as the 41 st in eparticipation ranking [15].

It is argued that closer ties between Government and Society through ICTs use must start from the most basic levels of participation, especially by providing information on public services. The aim of this work is to examine public services provision by the Government and the use of these services by Society. The effectiveness of this interaction comprises: (i) availability of relevant information about the services; (ii) possibility of expression by those involved in the public services; (iii) use of participants' comments as a basis of Citizen discussion; and (iv) the organization of participants' comments as an input to service improvement identification.

Usually, Society express itself via links like "Contact us", at government sites, or via Ombudsman offices provided by public agencies responsible for service delivery. Citizens can send pre-classified messages (suggestions, praise, criticism, etc.), to be received by an internal public agent, and may be answered or not, according to the agency relationship policy. Examples of such interaction are (a) the Ombudsman office of the Rio de Janeiro city hall [21], at which citizens may clarify doubts, request the use of a service and follow up a request, and (b) "Talk to President" and "Join the website" of the Presidency website [22], at which citizens can send messages to the presidential office, and send comments and suggestions on the website content.

In literature, it is possible to find research papers proposing the use of services as a way of establishing closer ties between Government and Society, in which Citizens may request use of these services and follow up their requests [23][24]. These proposals argue that online services can improve public service delivery in terms of availability, ease of use and lower costs; increase transparency and accountability; and alter the relationship between Government and Citizens. 
Berntzen [25] presents a new perspective about public participation, in which Government and Society work together in service delivery. Citizens are not only consumers of public services, but also comprise a resource which can add value to the existing government setup. It is argued that the Government is responsible for providing the infrastructure (servers, databases, software, etc.) and a basic set of public service information, and Society provides new information on these services.

Despite the potential of using services as a way to establish closer ties between Government and Society, most of the solutions proposed are focused on how to allow online service request in order to reduce existing bureaucracy and provide agility to the process. The solutions attempting to maintain a closer dialogue between Society and Government are focused on how to provide mechanisms allowing voting on preestablished matters and mechanisms through which Society can provide information about the service. The information provided by Society may or may not be used by Government for service improvement. Furthermore, these proposals do not explore the possibilities for discussion about the service provided and for stimulating interaction among citizens.

\section{Talking about Public Services}

The present work proposes the possibility of supporting conversations about public services for a closer relationship between Society and Government. Conversations are narratives made by those involved in discussions about services. Conversations are a common activity in public service contexts, especially in Brazilian culture. For instance, while standing in line, waiting to be served, people use to talk to one another, referring to the service issues, perceived problems, the way that attendees perform their work, documentation needed, etc. Usually people prefer to ask people in place about doubts or information, rather than going out for someone responsible for these issues in the room. In another context, while sitting at a bar table, or during any social interaction, people can talk about difficulties they had while trying to have some public service, like driving licenses. Others will surely have and express their own experiences or opinions, and what they did to avoid any problem. Others in the same social context will probably take this information and use it when their turn comes to have the same service provided.

However, in these situations, participants usually talk, complain or discuss with no familiarity with process details, especially those concerning how it can or must be provided by the public institution. When citizens are not aware of why the service must be provided that way, it may happen that complaints can be not useful and will require extra effort from the staff and from the public institution to treat them. Additionally, Government representatives or the public institution staff are not present or near enough to correct or explain any wrong view or information, leading to mistakes and dissatisfaction. Finally, the conversation is not recorded, and useful information which can be quickly used by others may be lost; only those who are physically present are able to participate or benefit from them.

Therefore, the proposed solution aims to support this kind of interaction in a virtual environment. The first argument of this proposal is that, to talk about services, citizens must have access to an explanation about how the service is provided. To this 
end, it is proposed that public services be presented in the form of process models [26]. This choice can take advantage of process management and modeling initiatives which possibly exist in the public organization. For example, in the Brazilian Government, we can find processes which explain how to declare the income tax [27] and how to transact laws in the Federal Congress [28].

Regardless of process representation chosen, it is argued that it is possible to create simple representations of the main process elements: objective (why the process exists), actors (who performs each process activity), activities (process steps), artifacts (inputs and outputs of activities), resources (equipment or systems that support activities), events (process triggers), business rules (laws which govern the process) and possible paths (decisions and alternatives in the process) [29] (Fig.1).

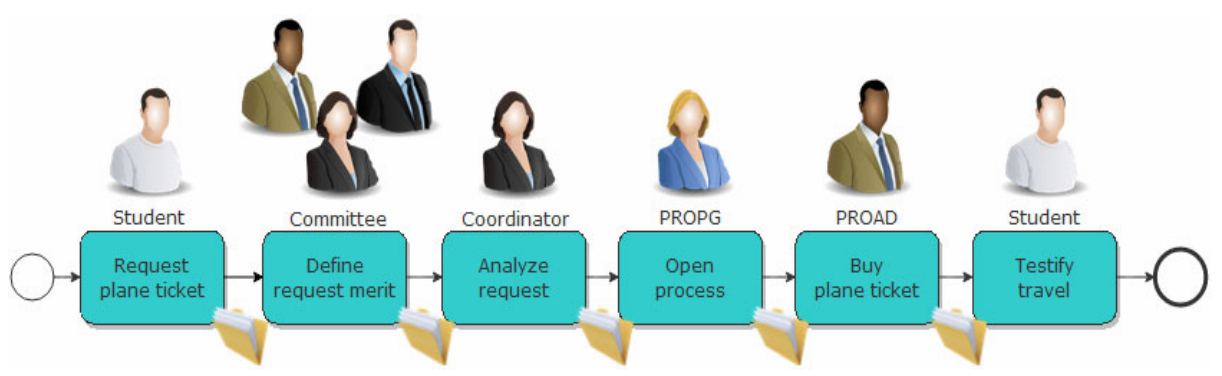

Fig. 1. Process model example

Once one is able to view how the service is provided as a process model, it is argued that citizens will be able to point their issues, complaints, experiences, and so on, to specific elements of this process - an actor, an activity, a rule etc. Thus, the proposed solution must offer participants the possibility of expressing themselves about any portion of the process or about any of its elements. This may help participants to better express their opinions, putting them into a context, while conversations can be kept focused on the service/process.

In order to enhance the possibility for sharing information, citizens can view other people's opinions, and comment on them, adding, correcting or just commenting on previous information. Government may also participate in, being, just like the citizens, a participant in this conversation. Government can also use the conversation to identify clues of the need of process improvement.

\section{Supporting Public Service Conversations}

To illustrate the proposal and explain the use of the tool, we will use a hypothetical scenario in which a student from a public university - Ann - attempts to have a service provided by this institution:

"Ann is a student in the first year of the Information Technology course of a Public University. She received an email informing her that the period for registration in disciplines is close and, to do so, she must access the registration system. Last semester, the registration was made personally, and Ann does not know how to proceed. 
Attempting to find some information about the topic, she decided to access the college website. She found that the college offers a list of all services rendered (Fig. 2). When she selected the service "Veterans' registration in discipline", she saw that it was represented by a description and a model showing the steps which are necessary for performing her registration. She also found that a description of each step of service is available, where she can discover who is responsible for execution, when to perform a step, the necessary documents etc (Fig. 3)."

The environment presents an overview of services provided by the organization, from which participants have visibility of how organization works (Fig. 2). The details for all services provided by the organization can be accessed from the organizational view. This presents a model and a description explaining service operation, and a description for each process activity (Fig. 3).

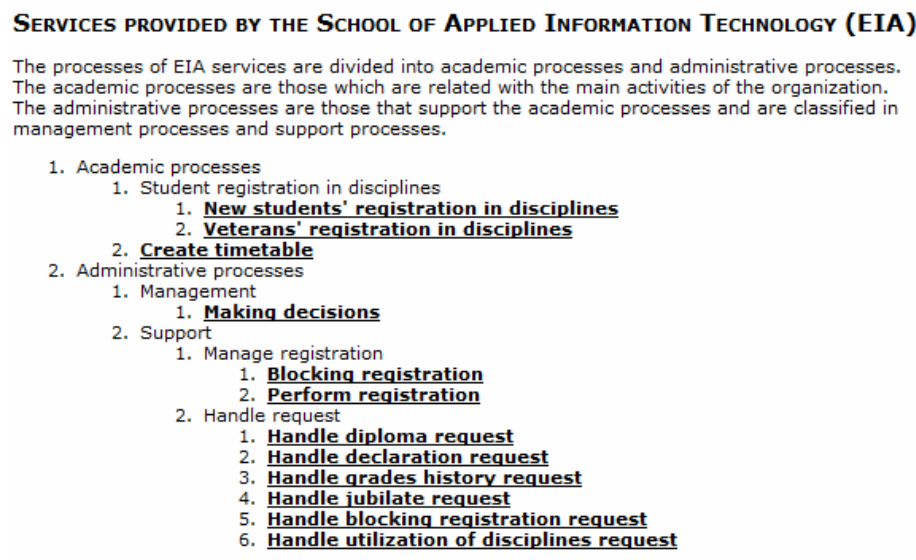

Fig. 2. Organization view

\section{VETERANS' REGISTRATION IN DISCIPLINE}

1. Student requests registration in discipline

2. Tutor schedules a week for confirmation of registration in discipline Week for confirmation confirmation of registration in discipline

3. Student and tutor verify the request of registration in disciplines

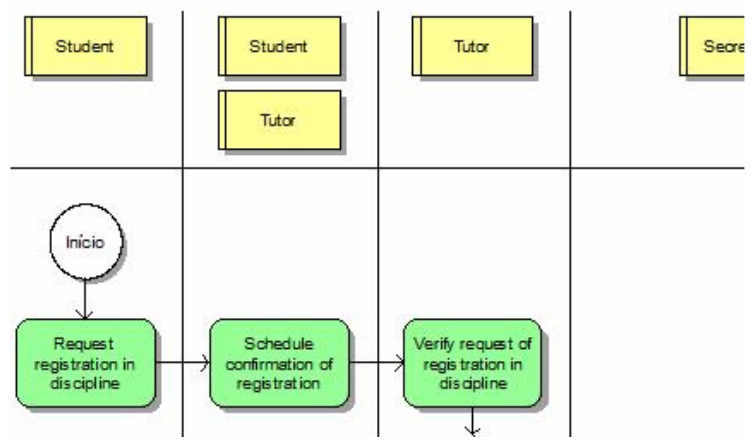

Fig. 3. Service details 
"When she had finished reading the description of the service, she felt a lack of information: last semester the system had a problem and it did not register her in a discipline. She only discovered this when her name was not on the list of students in the discipline. She believes a step is missing in the model by which students in this situation are informed. But how to communicate this situation to the service manager?

While she thought about it, she noticed the existence of some circles, in different colors, next to each process step (Fig. 4). Curious, she discovered that they represent positive, neutral and negative positions. But what are these positions? Clicking on one of the circles, she saw several comments. Reading its content (Fig. 5a), Ann discovered that they were related to the "Veterans' registration in discipline" and that they had been made by members of the college (Mark was her teacher and director of the college, and John was a veteran student who went to disciplines with her)."

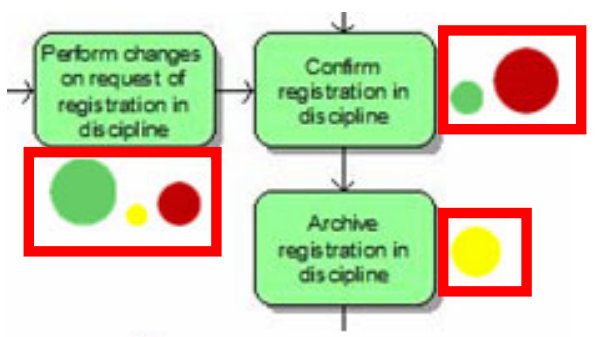

Positive comment

Neutral comment

Negative comment

Fig. 4. Comment visualizations

\section{Veterans' REgISTRATION IN DISCIPLINE}

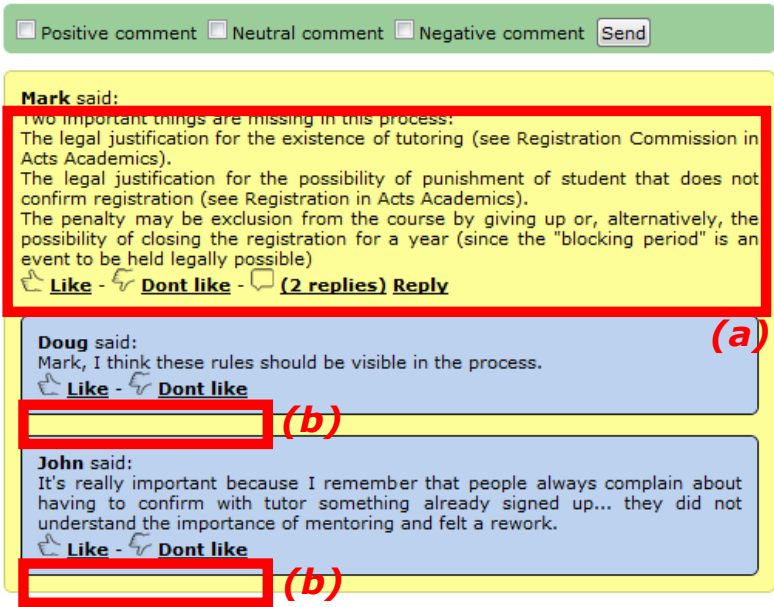

Fig. 5. Comment details 
It is possible to generate visualizations about what is being said during the conversation (Fig. 4). Visualizations are generated for each process element depicted in the model (activity, actor, etc) (Fig. 5).

"Now Ann discovered that she could pose comments about services and how to do it, Ann decided to report the lack of this communication. She has indicated on the form (Fig. 6) that this was a negative position and has commented: "It is possible to sit in class without being registered. A step is missing where the system notifies students that an error occurs in registration"."

Participants may pose their experiences, opinions, questions, problems, suggestions, etc., about the process. They should point out the process element to which the comment will be made, and indicate if this is a positive, neutral or negative comment to the process (Fig. 6).

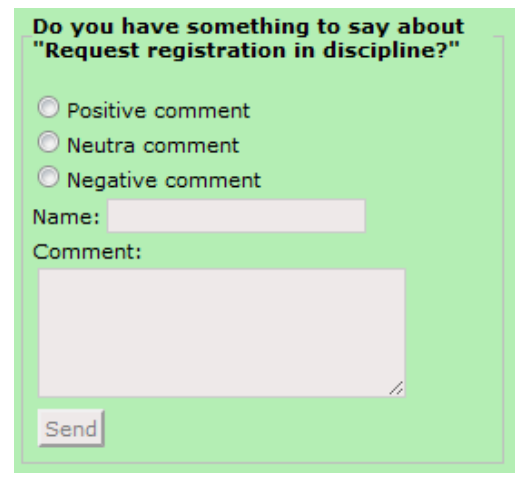

Fig. 6. Position about an activity

"After a few days, Ann received an email explaining that Christine had responded to her comment about "Veterans' registration in discipline". When Ann accessed the environment, she discovered that she was not the only one who had gone through that situation. The same thing happened to Christine, who reinforced the need to create a new step to inform students who had problems."

The tool provides mechanisms which enabling interactions among them (Fig. 5b). It provides the possibility of establishing a dialogue between participants, which increases the knowledge about the service and encourages conversations. After learning service details, participants can report new information about the process, as well as problems in previously-provided information and suggestions for solving difficulties and inconsistencies encountered. Comments may be used by other participants as an argument, or as complement to the previously-provided information.

"Besides Christine, Paul, who is responsible for the services provided by the college, also read the statements made on the tool. He can retrieve the comments mentioned in tool and use them to identify the snippets of text which indicate possibilities for service improvements (Fig. 7). He can also discover which content has generated more discussions (Fig. 8) or which members of the college most express themselves about the service (Fig. 9)." 


\section{$\mathbf{B} \mid \frac{\square}{7}$}

Mark disse: Two important things are missing in this process: The legal justification for the existence of tutoring (see Registration Commission in Acts Academics). The legal justification for the possibility of punishment of student that does not confirm reaistration (see Reaistration in Acts Academics). The penalty may be exclusion from the course by aivino un or. alternatively. the nossibility of closing the reaistration for a vear (since the "blocking period" is an event to be held legally possible). (uma manifestação 2) no dia 2010-10-19 às 11:44:00

Doug disse: Mark, I think these rules should be visible in the process. (uma manifestação 3) no dia 2010-10-19 às 14:11:00

John disse: It's really important because I remember that people always complain about having to confirm with tutor something already signed up... they did not understand the importance of mentoring and felt a rework. (uma manifestação 3 ) no dia 2010-10-22 às 11:01:00

Fig. 7. Comment analysis

Besides contributing to citizens' interaction, comments can help process analysis. The process manager can perform analyses to identify clues of the need for process changes and improvements (Fig. 7)(Fig. 8)(Fig. 9).

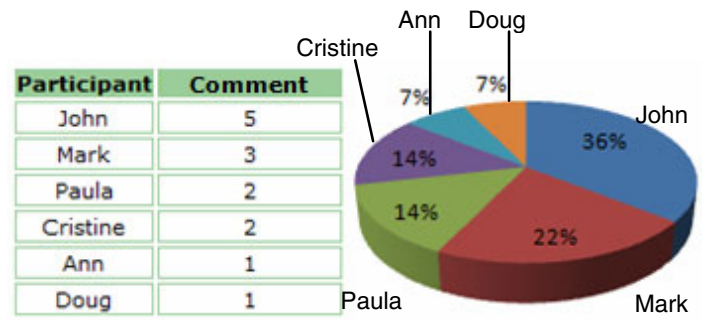

Fig. 8. Most active participants

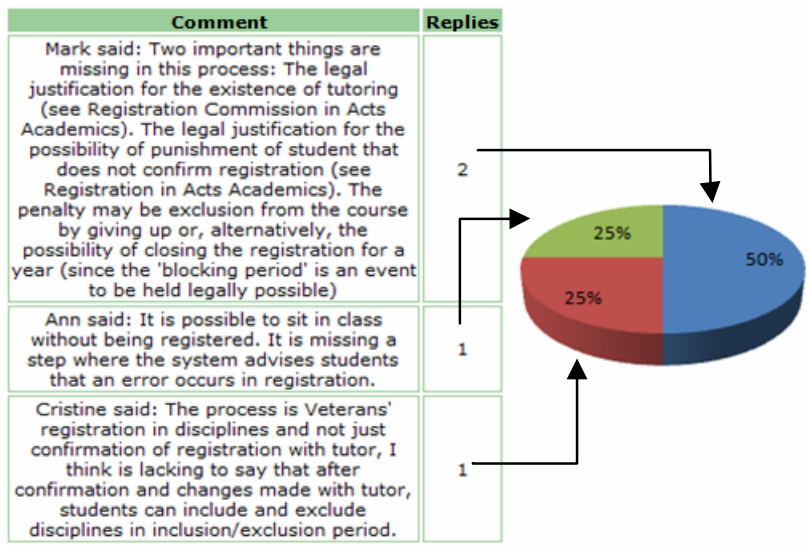

Fig. 9. Position about an activity 


\section{Conclusion}

This paper presented the specification of an environment supporting conversations among citizens and Government about public services. It is argued that the process model keeps the conversation focused and provides visibility to information on the operational services, often unknown to Society.

The main benefits of the proposed solution are alignment with organizational initiatives in process management, greater involvement and participation of Society in government service, possibility of interaction between Citizens in public service discussions, and identification of service improvements from comments made by Society, which may be invisible to managers.

As future work, studies will be conducted to identify how to insert this environment into the Federal University of the State of Rio de Janeiro (UNIRIO) context, through its website. The services provided by UNIRIO will be available to its community, so that citizens may know about, and interact with them, and with each other, by exchanging ideas and process improvements. Through this interaction, it is expected that the inputs secured allow for visualization construction and evaluation of use of conversations about public processes as a mechanism to facilitate greater interaction between the organization and citizens.

Acknowledgement. This research work is part of the project "Democracy, Transparency and Public Administration - Reflections and Implementations of Government Systems through ICTs" (http://www.uniriotec.br/ agora), sponsored by CAPES and $\mathrm{CNPq}$, and part of the Brazilian Webscience Institute $(\mathrm{CNPq}$ 557.128/2009-9 and FAPERJ E-26/170028/2008).

\section{References}

1. Maia, R.: Democracia e a internet como esfera pública virtual: Aproximando as condições do discurso e da deliberação (Democracy and the Internet as a virtual public sphere: Approaching discourse and deliberation conditions), Universidade de Brasília (2001) (in Portuguese)

2. Macintosh, A.: Characterizing e-participation in policy-making, In: Proceedings of the 37th Hawaii International Conference on System Sciences (HICSS), Hawaii (2004)

3. Silva, S.P.: Graus de participação democrática no uso da Internet pelos governos das capitais brasileiras (Degrees of democractic participation in the use of the Internet by the Brazilian Government). Opinião Pública XI(2), 450-468 (2005) (in Portuguese)

4. Brasil. Carta de Serviços ao Cidadão (Charter of Services to Citizen) (2008), http: / /www.governoeletronico.gov.br/anexos / apresentacaocarta-de-servicos-ao-cidadao (in Portuguese)

5. Ministerio da Cultura, Consulta pública para reforma da Lei Rouanet (Public consultation to reform the Rouanet Law) (2009) (in Portuguese), http: / / www.blogs. cultura.gov.br/blogdarouanet/

6. Ministério da Justiça, Consulta pública do Marco Civil da internet (Public consultation of internet civil landmark) (2010) (in Portuguese), http: / / www. culturadigital.br/marcocivil/

7. Ministério da Saúde, Consulta pública do Sistema Único de Saúde (Public consultation of Health System), http://200.214.130.94/consultapublica/index.php (2010) (in Portuguese) 
8. Allen, C.: Tracing the Evolution of Social Software (2004), http://www.lifewithalacrity.com/2004/10/tracing_the_evo.html

9. Bryant, T.: Social Software in Academia. Educase Quarterly (6), 61-64 (2006)

10. Hague, B.N.: Digital Democracy: Discourse and Decision Making in the Information Age, 1st edn. Routledge, New York (1999)

11. Oates, S.: Introduction to media and politics. Sage Publications, Thousand Oaks (2008)

12. Shirky, C.: Here comes everybody: The power of organizing without organization. The Penguin Press (2008)

13. W3C. Melhorando o acesso ao governo com o melhor uso da web (Improving access to government with best use of the Web) (2009) (in Portuguese), http: / /www.w3c.br/divulgacao/pdf/gov-web.pdf

14. Gomes, W.: Transformações da política na era da comunicação de massa (Politics transformation in the mass communication era), Paulus (2004) (in Portuguese)

15. Dutta, S., Mia, I.: The global information technology report 2009-2010 - ICT for sustainability. In: World Economic Forum (2010)

16. Grönlund, Å.: ICT Is Not Participation Is Not Democracy - eParticipation Development Models Revisited. In: Macintosh, A., Tambouris, E. (eds.) ePart 2009. LNCS, vol. 5694, pp. 12-23. Springer, Heidelberg (2009)

17. Arnstein, S.: A ladder of citizen participation. Journal of the American Institute of Planners 35(4), 216-224 (1969)

18. Femers, S., Wiedemann, P.: Public participation in waste management decision making: Analysis and management of conflicts. Journal of Hazardous Materials 33, 355-368 (1993)

19. OECD, Citizens as partners, Handbook on information, consultation and public participation in policy-making (2001)

20. CGI.br, TIC Governo Eletrônico (2010), http: / / www.cetic.br/tic/egov/2010/index.htm

21. Portal da Prefeitura do Rio (2011), http: / /www.rio.rj.gov.br

22. Brasil (2011), http: / / www . brasil.gov. br

23. Hwang, J., Manandhar, S.: Cost-benefit analysis of OPEN system: A case study for Kathmandu Metropolitan City. In: Proceedings of the 4th International Conference on Computer Sciences and Convergence Information Technology (ICCIT 2009), Seoul, pp. 14251430 (2009)

24. Miah, S., Gammack, J., Greenfield, G.: An infrastructure for implementing e-participation services in developing countries. In: Proceedings of the 3rd IEEE International Conference on Digital Ecosystems and Technologies (DEST 2009), Istambul, pp. 407-411 (2009)

25. Berntzen, L.: Enhanced e-Services through partnerships - Increasing the value of public infrastructure investments. In: Proceedings of the First International Conference on the Digital Society (ICDS 2007), Guadalupe, p. 20 (2007)

26. Business Dictionary (2011), http://www.businessdictionary.com/definition/process.html

27. Receita Federal, Declaração do Imposto sobre a Renda da Pessoa Física (Declaration of Incoming Tax) (2011) (in Portuguese),

http://www.receita.fazenda.gov.br/PessoaFisica/IRPF/2011/

Default.htm

28. Câmara dos Deputados, Tramitação de um projeto de lei ordinária (Ordinary Law Processing) (2011) (in Portuguese), http://www2.camara.gov.br/atividadelegislativa/processolegislativo/fluxo/plTramitacao

29. Sharp, A., Mcdermott, P.: Workflow modeling: Tools for process improvement and application development. Artech House Publishers, Boston (2001) 